\title{
ANALISIS KELAYAKAN FINANSIAL BUDIDAYA SENGON (Studi Kasus : Perusahaan Perseorangan di Desa Bojong Jengkol, Kecamatan Ciampea, Kabupten Bogor)
}

\section{Andreas Rumata Simanjuntak}

\author{
Program Studi Agribisnis, Fakultas Agro Teknologi, Universitas Prima Indonesia, Jl.Danau \\ Singkarak, Gang Madrasah, Medan Barat, Kota Medan, Sumatera Utara \\ andreasrumatasimanjuntak@unprimdn.ac.id
}

\begin{abstract}
ABSTRAK
Kabupaten Bogor merupakan salah satu penghasil Sengon tertinggi di Jawa Barat. Sengon terkenal murah dan mudah digunakan sebagai kayu untuk industri hasil hutan. Hal ini membuatnya sangat cocok untuk dibudidayakan baik oleh perusahaan besar maupun perusahaan swasta. Bapak A adalah salah satu yang membudidayakan sengon pada pemilik usaha perorangan di Desa Jengkol Bojong Kecamatan Ciampea Kabupaten Bogor. Perkebunan ini sudah berjalan selama tiga tahun tetapi terlihat diameter kayu kecil sehingga jarak tanam antar tanaman terlalu rapat. Oleh karena itu, perlu dilakukan studi kelayakan usaha untuk budidaya tanaman sengon ini di perusahaan swasta milik Bapak A. Tujuan dari penelitian ini adalah untuk mengidentifikasi kelayakan dari aspek finansial, dan juga kepekaan terhadap penurunan harga output yang lebih rendah dan penurunan imbal hasil. Hasil penelitian ini menunjukkan dari aspek finansial usaha ini layak untuk dilakukan. Dari segi sensitivitas, usaha ini layak untuk perubahan parameter tidak melebihi batas yang telah ditentukan.
\end{abstract}

Kata kunci: Sengon log, Budidaya Sengon, Analisis Kelayakan, Analisis Sensitivitas.

\section{ABSTRACT}

Bogor regency is one of the highest Sengon producers in west java. Sengon famous in its cheap and easy to use as a timber for the forest products industry. This makes it very suitable for cultivation by both large corporations and private firms. $\mathrm{Mr} A$ is one that cultivates sengon in individual business owners in the village of Bojong jengkol sub Ciampea Bogor regency. This farm has been running for three years but it looks small diameter timber resulting spacing between plants that are too close. Therefore, it is essential to make a business feasibility study for the cultivation of this sengon in $\mathrm{Mr}$ A's private firms. The purpose of this study was to identify the feasibility of financial and non financial aspects, and also sensitivity to the decline in output prices lower and yields decline. The results of this study indicate that from the financial aspect, this business is feasible to do. In terms of sensitivity, the business is feasible for parameter changes do not exceed a predetermined limit.

Keywords: Sengon log, Sengon cultivation, Feasibility analysis, Sensitivity analysis.

\section{Pendahuluan}

Indonesia merupakan negara

yang memiliki sumber daya hutan

yang sangat besar. Hutan memiliki peran penting dalam peradaban manusia. Salah satu hasil hutan yang banyak dimanfaatkan 
oleh manusia adalah kayu. Kayu dapat digunakan sebagai alat-alat sederhana, bahan energi (kayu bakar) hingga produk perumahan. Memasuki Abad 21, pembangunan kehutanan Indonesia dihadapkan pada permasalahan yang makin kompleks yaitu Indonesia dikenal sebagai negara dengan laju pengurangan luas hutan alam yang terbesar di dunia. Pengurangan luas hutan tersebut terjadi akibat proses laju penurunan mutu hutan (degradasi) dan penggundulan hutan (deforestasi). Beberapa studi menunjukkan laju degradasi dan deforestasi hutan di Indonesia mencapai rata -rata 1-1,5 juta hektar pertahunnya Salah satu cara untuk mengurangi degradasi dan deforestasi hutan di Indonesia adalah dengan peningkatan luas hutan tanaman.

Di Indonesia salah satu provinsi penghasil kayu terbesar adalah provinsi jawa barat. Di provinsi Jawa Barat, kayu yang umumnya ditanam adalah Sengon (Paraserianthes falcataria), Mahoni (Switenia mahgoni Jack), Jati (Tectona grandis), Karet (Hevea brasiliensis M.A.), Manii atau Kayu Afrika (Maesopsis emini), dan Pinus (Pinus merkusii). Areal hutan rakyat di kabupaten Bogor terdiri dari berbagai jenis tanaman dan yang terluas adalah sengon $(4.745,02$ ha) (Economics, 2004). Kayu ini sangat prospektif dari sisi ekonomi dan lingkungan. Hal ini disebabkan karena umur Sengon yang singkat dibanding pohon penghasil kayu umumnya dan sangat cocok untuk produk yang memerlukan pengolahan yang lebih lanjut.

Peluang dalam pembudidayaan Sengon ini menarik minat banyak perusahaan untuk berinfestasi dengan membudidayakan Sengon. Pak akun merupakan salah satu pemilik perusahaan perseorangan yang membudidayakan sengon di Desa Bojong Jengkol Kecamatan Ciampea Kabupaten Bogor. Dengan hadirnya usaha pembudidayaan sengon ini diharapkan tidak hanya menguntungkan bagi pemiliknya sendiri, tetapi juga memiliki manfaat bagi masyarakat sekitar dan sebagai manfaat intangible.

Dalam menghasilkan investasi yang optimum, penting diketahui kelayakan usaha sehingga cocok dikembangkan dalam jangka panjang. Selain itu, kondisi pasar yang tidak menentu dimana terjadinya penigkatan biaya dan penurunan harga jual Sengon sebaiknya diperkirakan sensitifitasnya terhadap kelayakan budidaya Sengon ini. Berdasarkan uraian tersebut, maka tujuan penelitian ini adalah sebagai berikut :

1. Menganalisis kelayakan usaha budidya sengon milik Bapak A dari aspek finansial.

2. Menganalisis perubahan-perubahan yang terjadi pada biaya dan penjualan terhadap kelayakan usaha budidaya Sengon dengan menggunakan analisis sensitivitas usaha tersebut.

\section{METODE PENELITIAN}

Metode pengolahan data dilakukan secara kuantitatif. Analisis secara kuantitatif dilakukan berkenaan dengan aspek finansial yaitu dengan menghitung Net Present Value (NPV), Internal Rate Of Return (IRR), Net B/C, Payback Periode (PP), dan analisis sensitivitas menggunakan alat bantu Microsoft Excel.

\section{Analisis Aspek Finansial dan Kriteria Investasi}

1. Net Present Value (NPV),

Menurut Kasmir dan Jakfar, (2003) NPV merupakan selisih antara present value dari benefit dan present value dari biaya. Dalam evaluasi suatu usaha tertentu, nilai NPV $\geq 0$ menandakan bahwa usaha tersebut layak untuk dijalankan. Jika NPV $=0$, berarti usaha tersebut mengembalikan tepat sebesar social opportunity cost of capital. Jika NPV < 0, usaha tersebut tidak layak untuk dijalankan. Penentuan nilai NPV 
dapat dituliskan sebagai berikut:

$$
N P V=\sum_{t=1}^{n} \frac{B t-C t}{(1+i)^{t}}
$$

\section{Internal Rate of Return (IRR),}

IRR merupakan tingkat keuntungan atas investasi bersih dalam suatu usaha (Kasmir dan Jakfar, 2003). Setiap benefit bersih yang diwujudkan secara otomatis ditanam kembali dalam tahun berikutnya dan mendapatkan tingkat keuntungan suku bunga yang sama yang diberi bunga selama sisa umur usaha. Jika ternyata IRR dari suatu usaha sama dengan nilai i yang berlaku sebagai social discount rate, maka NPV dari usaha itu adalah sebesar 0. Jika IRR < social discount rate, maka NPV < 0 . Usaha ini menggunakan modal sendiri, nilai discount rate yang digunakan adalah berdasarkan suku bunga deposito. Oleh karena itu, suatu nilai IRR yang lebih besar daripada atau sama dengan social discount rate menunjukkan suatu usaha layak dijalankan, sedangkan IRR kurang dari social discount rate-nya memberikan tanda tidak layak untuk dijalankan. Penentuan nilai IRR sebagai berikut:

$I R R=i_{1}+\frac{N P V_{1}}{N P V_{1}-N P V_{2}}\left(i_{2}-i_{1}\right)$

\section{Net Benefit Cost Ratio (Net B/C),}

Net B/C rasio merupakan perbandingan sedemikian rupa sehingga pembilangnya terdiri atas present value total dari benefit bersih dalam tahun-tahun dimana benefit bersih tersebut bersifat positif, sedangkan penyebutnya terdiri atas present value total dari biaya bersih dalam tahun-tahun tertentu dimana biaya kotor lebih besar daripada benefit kotor (Kasmir dan Jakfar, 2003). Net $\mathrm{B} / \mathrm{C} \geq 1$ menandakan bahwa usaha layak untuk dijalankan dan bila Net $\mathrm{B} / \mathrm{C}<1$ menandakan bahwa usaha tidak layak untuk dijalankan. Penentuan Net B/C sebagai berikut

$$
\text { Net } \frac{B}{C}=\frac{\sum_{t=1}^{n} \frac{B t-C t}{(1+i)^{t}}}{\sum_{t=1}^{n} \frac{C t-B t}{(1+i)^{t}}}
$$

\section{Payback of Period (PBP)}

PBP adalah salah satu metode dalam menilai kelayakan suatu usaha yang digunakan untuk mengukur periode pengembalian modal. Dasar yang digunakan untuk perhitngan adalah aliran kas (cash flow). Cara perhitungan PBP ini ada beberapa macam dan cara perhitungan yang dipilih dalam penelitian ini adalah menutup biaya investasi yang dikeluarkan dengan aliran kas bersih pada tahun-tanun berikutnya sampai biaya investasi tersebut dapat ditutup (Umar, 2003). PBP dapat dihitung dengan menggunakan rumus:

$$
\mathrm{PP}=\frac{I}{A_{b}}
$$

\section{Analisis Sensitivitas dan Switching Value}

Analisis sensitivitas merupakan suatu analisis untuk dapat melihat pengaruhpengaruh yang akan terjadi akibat keadaan yang berubah-ubah. Bisnis sangat sensitif atau peka terhadap perubahan akibat beberapa hal, yaitu : (1) perubahan harga (terutama harga output), (2) keterlambatan, (3) kenaikan biaya ("cast over run"), (4) ketidaktepatan dan perkiraan hasil (produksi). Terutama bila cara produksi baru yang sedang diusulkan yang dipakai sebagai ukuran atau informasi agronomis terutama didasarkan pada hasil penelitian. Analisis sentivitas dilihat terhadap kelayakan bisnis terhadap perbedaan dari perkiraan hasil bisnis dengan hasil yang betul-betul dihasilkan di lokasi bisnis. 
HASIL DAN PEMBAHASAN Analisis Kelayakan Aspek Finansial

\section{Arus Kas Masuk}

1. Pendapatan Penjualan

Pendapatan penjualan dihitung dari perkiraan jumlah produksi dikalikan dengan harga jual. Pada tahun pertama hingga tahun kelima, perusahaan pembudidaya Sengon ini tidak berproduksi karena, tidak melakukan sistem tumpangsari dan target pembudidayaan Sengon yang dilakukan adalah lima tahun, sehingga tidak dihasilkan apapun dari lahan pembudidayaan. Target dari perusahaan pembudidaya Sengon ini adalah $90.000 \mathrm{~m}^{3}$ kayu Sengon. Perusahaan pembudidaya Sengon ini berproduksi degngan menyiapkan 185.000 bibit Sengon, namun dalam kondisi di lokasi penelitian dua dari sepuluh batang Sengon mati. Hal ini dapat diakibatkan jarak tanam yang terlalu dekat serta kondisi yang disebabkan oleh alam seperti angin maupun hama. Kematian beberapa pohon Sengon ini diperhitungkan sebagai mortalitas yang diasumsikan sebesar 20 persen. Ukuran diameter Sengon untuk dipanen umumnya diperkirakan $20 \mathrm{~cm}$. Harga jual kayu Sengon per meter kubik untuk kayu berdiameter 20-24 cm adalah $\mathrm{Rp}$ 600.000. Untuk kayu berdiameter 25$29 \mathrm{~cm}$, per meter kubik dihargai senilai Rp 820.000. Karena itu, diameter kayu yang dihasilkan sebaiknya diatas 25 $\mathrm{cm}$ untuk menghasilkan keuntungan yang jauh lebih besar. Pada akhir tahun kelima dilakukan pemanenan dengan perkiraan jumlah 150.000 kayu berukuran $0.22 \mathrm{~m}^{3}$ dan berdiameter 20 $\mathrm{cm}$. Dengan harga Rp 600.000 per meter kubik kayu Sengon, pendapatan yang diterima perusahaan pembudidaya Sengon ini dari penjualan kayu Sengon saat panen adalah Rp 19.800.000.000.
2. Nilai Sisa

Penerimaan lain yang diperoleh perusahaan pembudidaya Sengon ini adalah dari nilai sisa atau salvage value. Nilai sisa merupakan nilai sisa barang modal yang tidak habis terpakai selama umur usaha berlangsung dan dinilai saat umur usaha berakhir. Barang-barang modal perusahaan pembudidaya Sengon ini yang memiliki nilai sisa adalah lahan. Perusahaan pembudidaya Sengon ini membuka usaha di lahan yang luasnya $35 \mathrm{Ha}$. Lokasi usaha berada 3 kilometer dari jalan protokol. Harga rata-rata lahan per $\mathrm{m}^{2}$ adalah $\mathrm{Rp}$ 10.000, sehingga nilai lahan yang dimiliki perusahaan pembudidaya Sengon ini adalah senilai $\mathrm{Rp}$ 3.500.000.000. Lahan tidak mengalami penyusutan, sehingga nilainya pada akhir usaha sama dengan nilai awalnya yaitu, $\mathrm{Rp}$ 3.500.000.000.

\section{Arus Pengeluaran (Outflow)}

1. Biaya Investasi

Biaya investasi merupakan biaya yang dikeluarkan pada saat awal proyek. Total biaya investasi yang dikeluarkan perusahaan pembudidaya Sengon ini dalam menjalankan usahanya adalah Rp 4.438.150.000.

2. Biaya Operasional

Biaya operasional adalah biaya yang dikeluarkan secara berkala selama usaha berjalan. Biaya operasional meliputi, biaya tetap dan biaya variabel.

Biaya tetap yang dikeluarkan oleh perusahaan pembudidaya Sengon ini untuk budidaya Sengon adalah gaji karyawan tetap, administrasi kantor, biaya komunikasi, PBB, dan uang keamanan. Rincian biaya tetap dapat dilihat dari penjabaran berikut:

1) Tenaga kerja tetap yang dimiliki perusahaan pembudidaya Sengon ini 
adalah lima orang dengan gaji masing-masing adalah $\mathrm{Rp} 150.000$ per minggu. Dengan demikian, biaya gaji karyawan tetap perusahaan pembudidaya Sengon ini dalam setahun adalah $\mathrm{Rp}$ 31.200.000.

2) Biaya aministrasi kantor dalam satu tahun adalah Rp 2.000.000.

3) Biaya komunikasi yang dikeluarkan perusahaan pembudidaya Sengon ini dalam menjalankan kegiatan usahanya selama satu tahun adalah $\mathrm{Rp}$ 1.000.000. Dengan asumsi, biaya komunikasi per bulannya adalah $\mathrm{Rp} 80.000$.

4) Biaya pajak bumi dan bangunan untuk lahan per tahunnya adalah $\mathrm{Rp}$ 10.000.000.

5) Biaya keamanan dari pihak kepolisian adalah Rp 20.000.000 per tahun. Dari rincian biaya tetap di atas, diperoleh nilai dari total biaya tetap yang dikeluarkan adalah $\mathrm{Rp}$ 64.200 .000

Biaya variabel yang dikeluarkan perusahaan pembudidaya Sengon ini dalam pembudidayaan Sengon terdiri atas biaya upah harian, kotoran kambing sebagai pupuk kandang, pupuk kimia, pestisida, herbisida, penyewaan eskavator dan transportasi (bahan bakar mesin). Rincian biaya variabel dapat dilihat dari penjabaran berikut.

1) Biaya upah tenaga kerja harian perusahaan pembudidaya Sengon ini terdiri atas pembudidayaan selama tahap persiapan lahan, tahun pertama, dan tahun kedua pembudidayaan Sengon. Biaya upah harian merupakan biaya yang dikeluarkan untuk membayar upah tenaga kerja yang membantu proses produksi. Pada tahap persiapan lahan, pekerja harian yang akan dipekerjakan adalah sebanyak tiga puluh orang dengan gaji masingmasing adalah Rp 50.000 per hari. Dengan demikian, total biaya upah harian selama satu tahun pada tahun pertama adalah $\mathrm{Rp}$ 602.250.000. Selain itu, pada tahap persiapan lahan dilakukan penyewaan tiga unit eskavator. Setiap pengemudi eskavator diberi upah Rp 50.000 per hari, sehingga dalam satu tahun upah ketiga pengemudi eskavator adalah $\mathrm{Rp}$ 54.750.000. Pada tahun pertama pembudidayaan jumlah pekerja sama dengan tahap persiapan lahan, namun hanya dibutuhkan 14 hari dalam satu bulan dengan gaji $\mathrm{Rp}$ 50.000. Total biaya upah harian selama satu tahun pada tahun pertama pembudidayaan adalah $\mathrm{Rp}$ 252.000.000.

2) Kotoran Kambing dibutuhkan dalam penanaman bibit Sengon, yaitu sebagai pupuk dasar sebelum diletakkannya bibit Sengon pada lobang tanaman. Harga pupuk kandang ini adalah Rp 5.000 per karung. Dibutuhkan 3700 karung kotoran kambing untuk seluruh lobang tanaman. Total biaya untuk pembelian pupuk kandang ini adalah Rp 18.500.000

3) Pupuk kimia yang mengandung Urea, Furadan dan KCL dibutuhkan selama proses pembudidayaan dalam tahun pertama dan kedua. Harga pupuk urea, furadan dan pupuk KCL masing masing adalah Rp 200.000. Dalam pembudidayaannya dibutuhkan perbandingan yang sama antara pupuk urea, furadan dan pupuk KCL untuk pemupukan. Pada tahun pertama dibutuhkan masing-masing 72 karung pupuk urea, furadan dan pupuk KCL sehingga total biaya untuk pembelian pupuk kimia adalah Rp 43.200.000. untuk tahun kedua dibutuhkan masing-masing 24 karung pupuk urea, furadan dan pupuk KCL, sehingga total biaya untuk pembelian pupuk kimia pada tahun kedua adalah Rp 14.400.000. 
4) Pestisida dibutuhkan baik dalam proses persiapan penanaman Sengon. tahun pertama pembudidayaan, dan tahun kedua pembudidayaan. Pada persiapan penanaman Sengon, dibutuhkan Dimecron yang disemprotkan ke akar bibit sebagai pencegah adanya hama. Pada tahap ini dibutuhkan 28 liter Dimecron seharga $\mathrm{Rp} 50.000$ sehingga totalnya adalah $\mathrm{Rp}$ 1.400.000. Pada tahun pertama pembudidayaan Sengon dibutuhkan Dimecron dalam penyemprotan tanaman Sengon. dibutuhkan 47 liter Dimecron dan Perfection seharga Rp 50.000 per liter, sehingga totalnya adalah $\mathrm{Rp}$ 62.125.000. Pada tahun kedua pembudidayaan dibutuhkan lebih banyak pestisida dalam mengeantisipasi tanaman Sengon yang telah menjadi lebih besar. Dibutuhkan Dimecron dan Perfection sebanyak 75 liter sehingga totalnya adalah $\mathrm{Rp}$ 45.000.000

5) Pada tahap persiapan lahan Sengon, selain dibersihkan dari pepohonan kecil dan bambu, lahan juga dibersihkan dari rumput dengn herbisida. Dibutuhkan dua buah drum sodium chloerate untuk 35 ha lahan. Harga satu drum herbisida ini adalah Rp 270.000 sehingga total biaya untuk pembongkaran lahan dengan herbisida adalah $\mathrm{Rp}$ 540.000 .

6) Dalam tahap persiapan lahan dibutuhkan tiga unit esakvator yang bekerja sembilan jam perhari dengan tarif penyewaan Rp 100.000 per jam. Eskavator ini dibutuhkan setiap hari sehingga dalam satu tahun persiapan lahan dibutuhkan biaya sebesar Rp 985.500.000 untuk penyewaan alat berat berupa eskavator.

7) Penyewaan eskavator membutuhkan 100 liter solar per hari untuk setiap eskavator, sehingga biaya yang dibutuhkan untuk bahan bakar mesin eskavator adalah $\mathrm{Rp}$ 383.250.000

8) Pengantaran pupuk dari penjual pupuk di garut, membutuhkan satu unit truk Fuso. Pengangkutan ini dikenakan biaya Rp 500.000 setiap pengantaran pupuk. Pengantaran ini dibutuhkan pada tahun pertama pembudidayaan Sengon saja karena sudah mengangkut kebutuhan pupuk untuk dua tahun pembudidayaan Sengon.

\section{Analisis Laba Rugi}

Analisa laba rugi digunakan perusahaan untuk mengetahui perkembangan usaha dalam periode tertentu. Komponen laba rugi usaha perusahaan pembudidaya Sengon ini ini terdiri atas, pendapatan penjualan hasil produksi, biaya operasional, biaya penyusutan, beban bunga, dan pajak penghasilan. Laba sebelum pajak (EBT) diperoleh dari pendapatan penjualan dikurangi dengan biaya operasional, beban bunga, dan biaya penyusutan. Laba setelah pajak (EAT) diperoleh dari laba sebelum pajak dikurangi dengan pajak penghasilan. Pembebanan pajak penghasilan dihitung berdasarkan ketentuan UU RI No.36 Tahun 2008 tentang pajak penghasilan badan usaha. Perusahaan pembudidaya Sengon ini mempunyai target pemanenan hingga tahun kelima sehingga tidak memperoleh keuntungan mulai tahun pertama sampai tahun ke empat. Keutungan atau ruginya didapat pada tahun kelima berdsarkan analisa laba rugi.

\section{Analisis Finansial}

Analisis kelayakan finansial perusahaan pembudidaya Sengon ini menggunakan prinsip nilai uang saat ini tidak sama dengan nilai uang dimasa akan datang. Analisis ini dilakukan dengan menggunakan kriteria-kriteria penilaian investasi yaitu, Net Present Value (NPV), 
Internal Rate of Return (IRR), Net Benefit-Cost Ratio (Net B/C), dan Payback Period (PBP). Hasil analisis finansial menunjukkan bahwa NPV usaha pembudidayaan Sengon ini lebih besar dari nol yaitu, Rp 3.453.596.052. Hal ini menunjukkan usaha yang akan dijalankan perusahaan pembudidaya Sengon ini diperkirakan memberikan manfaat bersih sebesar Rp 3.453.596.052 selama kurun waktu 5 tahun dengan kapasitas produksi menghasilkan 150.000 batang kayu Sengon berdiameter $20 \mathrm{~cm}$ dalam lima tahun. Dengan demikian, berdasarkan kriteria NPV usaha ini layak untuk dilaksankan.

Nilai IRR yang diperoleh yaitu sebesar 14 persen dimana IRR tersebut lebih besar dari discount factor yang berlaku yaitu, 5 persen. Hal ini menunjukkan tingkat pengembalian yang diberikan usaha dari modal yang telah diinvestasikan adalah sebesar 14 persen. Hal ini juga menunjukkan bahwa pengembalian yang diberikan usaha lebih besar dibandingkan dengan tingkat suku bunga deposaito. Dengan demikian, berdasarkan kriteria IRR usaha ini layak untuk dilaksanakan.

Net B/C yang diperoleh adalah sebesar 1,488. Hal ini berarti setiap Rp 1 biaya yang dikeluarkan untuk menjalankan usaha ini akan menghasilkan manfaat bersih sebesar Rp 1,488. Hal ini juga menunjukkan bahwa pendapatan bersih yang diperoleh adalah 1,488 kali dari biaya. Nilai Net B/C yang dihasilkan lebih besar dari 1. Karena itu, usaha perusahaan pembudidaya Sengon ini layak untuk dilaksanakan.

Payback period yang diperoleh adalah 10,249 tahun atau sama dengan 10 tahun 2 bulan 29 hari. Hal ini berarti, usaha tidak dapat mengembalikan modal walaupun usaha pembudidayaan berakhir. Nilai Payback period ini lebih lama dari periode pembudidayaan, sehingga usaha ini berdasarkan PBP tidak layak untuk dijalankan.
Skenario dibuat dalam membandingkan sebuah usaha kondisi aktual dengan kondisi yang diharapkan terjadi. Salah satu skenario yang perlu dipertimbangkan adalah dengan mengganti salah satu sitem pembudidayaan kondisi aktual menjadi kondisi yang diharapkan sesuai dengan tata pembudidayaan berdasarkan literatur maupun penelitianpenelitian sebelumnya. Hal ini perlu dipertimbangkan karena kriteria infestasi yaitu PBP yang menunjukkan usaha ini sangat lama memperoleh laba. Lamanya laba ini diperoleh karena sistem pembudidayaan yang tidak tepat.salah satu sistem pembudidayaan yang tidak tepat ini adalah pembuatan jarak tanam. Untuk itu dibuat skenario jarak antar tanaman hingga dua kali lipat dari kondisi actual. Hal ini membuat pembelian bibit menjadi berkurang hingga 50 persen, namun pembelian bahan-bahan variabel diasumsikan tetap sama karena sistem pembudidayaan sebelumnya membuat pemupukan dan pencegaha penyakit seminimal mungkin. Diasumsikan juga diameter kayu saat panen adalah $27 \mathrm{~cm}$ yang membuat harganya lebih tinggi dibandingkan rencana panen kondisi actual. Mortilitas kayu diasumsikan hanya 5 persen karena sistem penanamannya tepat dan jarak tanaman tidak terlalu dekat. Perbandingan kondisi aktual dengan skenario pengurangan junlah bibit dapat dilihat dalam Tabel 1.

Tabel 1. Perbandingan Hasil Kelayakan Usaha pada Dua Skenario

\begin{tabular}{lll}
\hline $\begin{array}{c}\text { Kriteria } \\
\text { Kelayaka } \\
\text { n }\end{array}$ & \multicolumn{1}{c}{$\begin{array}{c}\text { Hasil } \\
\text { Kondisi } \\
\text { Aktual }\end{array}$} & $\begin{array}{c}\text { Skenario } \\
\text { Penguranga } \\
\text { n Jumlah } \\
\text { Bibit }\end{array}$ \\
\hline NPV & Rp 3.453.596.052 & Rp 7.563.496.958 \\
IRR & 14 persen & 33 persen \\
Net B/C & 1,488 & 1,976 \\
PBP & 10,249 & 4,99 Tahun \\
& tahun & \\
\hline
\end{tabular}




\section{Analisis Sensitifitas}

Usaha pembudidayaan kayu Sengon di desa bojong jengkol ini memiliki target usaha selama lima tahun. Hasil produksi didapatkan saat panen pada akhir tahun kelima pembudidayaan. Pembelian bahan input seperti pupuk kimia dan pestisida dibeli pada tahun pertama pembudidayaan untuk stok selama satu tahun. Demikian pula untuk tahun kedua, pupuk dan pestisida hanya dibeli dalam satu tahap untuk satu tahun. perlakuan pemberian pupuk dan pestisida juga hanya dilakukan selama dua tahun pembudidaaan. Dengan demikian, perubahan harga input tidak berpengaruh signifikan terhadap usaha ini.

Tingginya tingakat mortalitas kayu Sengon yang diasumsikan sebesar 20 persen membuat perubahan jumlah batang Sengon saat dipanen sangat perlu untuk dianalisis. Penurunan jumlah bantang Sengon yang diakibatkan kondisi tak terduga seperti penyakit, pencurian kayu Sengon, maupun tumbang akibat angin putting beliung dapat berpengaruh besar terhadap kriteria investasi pembudidayaan Sengon ini. Selain itu harga jual kayu Sengon per meter kubik juga perlu dianalisis karena harga Sengon perbatangnya memiliki proporsi besar dalam inflow usaha budidaya Sengon ini.

Dengan demikian, variabel yang dianalisis merupakan variabel yang dianggap signifikan terhadap usaha yaitu, harga jual kayu Sengon per meter kubik, dan penurunan jumlah kayu Sengon akibat mortalitas. Dalam analisis switching value akan diperoleh persentase penurunan harga maksimum kayu Sengon per meter kubik serta penurunan maksimum jumlah kayu Sengon akibat mortalitas yang membuat usaha ini masih tetap layak untuk dijalankan melalui analisis switching value. Hasil analisis switching value pada usaha perusahaan pembudidaya Sengon ini dapat dilihat pada Tabel 2.
Tabel 2. Hasil Analisis Switching Value perusahaan pembudidaya Sengon

Uraian $\begin{aligned} & \text { Switching Value } \\ & \text { (persen) }\end{aligned}$

\begin{tabular}{ll}
\hline $\begin{array}{l}\text { Harga jual kayu } \\
\text { Sengon }\end{array}$ & $\begin{array}{l}\text { Turun maksimal } \\
\text { sebesar 23,37 }\end{array}$ \\
$\begin{array}{ll}\text { Jumlah penurunan } \\
\text { hasil panen Sengon }\end{array}$ & $\begin{array}{l}\text { Turun maksimal } \\
\text { sebesar 23,37 }\end{array}$
\end{tabular}

Berdasarkan hasil analisis switching value, penurunan harga jual kayu Sengon maksimal sebesar 23,37 persen dan penurunan maksimal jumlah panen kayu Sengon sebesar 23,37 persen membuat usaha ini masih memperoleh keuntungan normal. Penurunan jumlah panen kayu Sengon lebih besar dari 23,37 persen dapat membuat usaha pembudidayaan Sengon ini tidak layak. Penurunan jumlah panen sebesar 23,37 persen dari perkiraan akan menghasilkan nilai NPV usaha yang lebih kecil dari nol atau negatif, IRR lebih kecil dari discount faktor, dan Net B/C juga akan lebih kecil dari nol.

Usaha budidaya Sengon ini menjadi tidak layak untuk dijalankan apabila harga kayu Sengon per meter kubik mengalami penurunan melebihi 23,37 persen. Penurunan harga sebesar 23,37 persen dari perkiraan akan menghasilkan nilai NPV usaha yang lebih kecil dari nol atau negatif, IRR lebih kecil dari discount faktor, dan Net B/C juga akan lebih kecil dari nol. Dengan demikian, berdasarkan kriteria investasi usaha ini layak untuk dilaksanakan. Apalagi, harga kayu Sengon per meter kubik memiliki kecenderungan yang semakin meningkat.

\section{KESIMPULAN}

Berdasarkan hasil deskripsi gambaran usaha, analisis kelayakan usaha, dan analisis switching value pada usaha $\begin{array}{lrr}\text { budidaya } & \text { Sengon } & \text { perusahaan } \\ \text { perseorangan } & \text { dapat } & \text { dirumuskan } \\ \text { kesimpulan } & \text { sebagai } & \text { berikut. }\end{array}$ 
1. Hasil analisis aspek finansial menunjukkan bahwa usaha ini layak untuk dilaksanakan. Nilai NPV yang dihasilkan selama kurun waktu lima tahun adalah $\mathrm{Rp}$ 3.453.596.052 dengan kapasitas produksi menghasilkan 150.000 kayu berukuran $0.22 \mathrm{~m}^{3}$. Nilai IRR yang diperoleh yaitu sebesar 14 persen dimana IRR tersebut lebih besar dari discount factor yang berlaku yaitu 14 persen. Net B/C yang diperoleh adalah sebesar 1,488. Hal ini berarti, setiap Rp 1 biaya yang dikeluarkan untuk menjalankan usaha ini akan menghasilkan manfaat bersih sebesar Rp 1,488. Payback period yang diperoleh adalah 10,249 tahun atau sama dengan 10 tahun 2 bulan 29 hari. Analisis Payback Periode menunjukkan pengembalian modal lebih lama dari proses pembudidayaan.

2. Berdasarkan hasil analisis switching value, penurunan harga jual kayu Sengon melebihi 23,37 persen dan penurunan jumlah panen kayu Sengon melebihi 23,37 persen membuat usaha ini menjadi tidak layak untuk dilaksanakan. Dengan demikian, usaha ini sangat peka baik terhadap penurunan harga jual maupun penurunan maksimal jumlah panen Sengon. Pembuatan scenario pemberian jarak tanam hingga dua kali lipat, yang mengurangi jumlah penggunaan bibit hingga 50 persen membuat usaha ini memiliki NPV Rp 7.563.496.958, nilai IRR sebesar 33 persen, Net B/C sebesar 1,976 dan masa pengembalian modalnya adalah 4,99 tahun.

\section{DAFTAR PUSTAKA}

Alex. 2011. Investasi Emas Hijau

Budidaya Sengon. Sleman. Pustaka

Bru Press.

Green Economics. 2004. Industry Pengolahan Kayu (Evolusi Terhadap

Perizinan Kewenangan, dan Pembinaan Industri Pengolahan Kayu). Jakarta: Green Economics
Edris M. 1985. Penuntun Melakukan Studi Kelayakan Proyek. Bandung: Sinar Baru.

Gittinger, J. P. 1986. Analisa Ekonomi Proyek-Proyek Pertanian. Jakarta: UI-Press.

Husnan, S dan Suwarsono. 1994. Studi Kelayakan Proyek. Edisi Revisi. Yogyakarta: UPP AMP YKPN.

Kasmir, Jakfar. 2003. Studi Kelayakan Bisnis. Edisi Kedua. Jakarta: Kencana Prenada Media Group.

Krisnawati H, Varis E, Kanninen M. 2011. Paraserianthes falcataria (L.) Nielsen: Ecology, silviculture and productivity. Bogor: Center for International Forestry Research.

Munawar A. 2010. Analisis nilai tambah dan pemasaran kayu sengon gergajian di Kecamata Cigudeg, Kabupaten Bogor [skripsi] Bogor: Fakultas Ekonomi dan Manajemen, Institut Pertanian Bogor.

Narunda VT. 2011. Studi kelayakan bisnis tanaman buah jambu kristal pada kelompok tani Desa Cikarawang, Kecamatan Darmaga, Kabupaten Bogor [skripsi] Bogor: Fakultas Ekonomi dan Manajemen, Institut Pertnian Bogor.

Palupi SN. Analisis kelayakan usaha pengembangan jarak pagar (Jatropha cucras L.) sebagai sumber energi alternatif di Desa Lempopacci, Kabupaten Luwu, Sulawesi Selatan [skripsi] Bogor: Fakultas Ekonomi dan Manajemen, Institut Pertanian Bogor.

Putra AE. 2006. Analisis sistem tataniaga kayu jenis sengon (Paraserientes falcataria) dan prosperk pengembangannya di Kecamatan Cililin , Kabupaten Bandung, Jawa Barat [skripsi]. Bogor: Fakultas Ekonomi dan Manajemen, Institut Pertanian Bogor.

Siregar UJ, Rachmi A, Massijaya MY. 2005. Economic analysis of sengon (Paraserianthes falcataria) community forest plantation, a fast growing species in East Java, 
Indonesia [jurnal] Bogor: Fakultas

Kehutanan, Institut Pertanian Bogor.

Umar, H. 2003. Studi Kelayakan Bisnis:

Tekik Menganalisis Kelayakan

Rencana Bisnis Secara

Komprehensif. Eidsi Kedua.

Jakarta: PT Gramedia Pustaka 